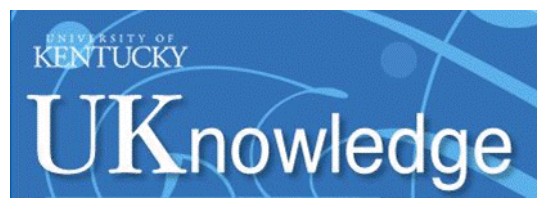

University of Kentucky

UKnowledge

\title{
Bumping Along the Bottom: Abandoned Principles and Failed Fiduciary Standards in Uniform Partnership and LLC Statutes
}

Rutheford B. Campbell Jr.

University of Kentucky College of Law, rcampbel@uky.edu

Follow this and additional works at: https://uknowledge.uky.edu/law_facpub

Part of the Business Organizations Law Commons

Right click to open a feedback form in a new tab to let us know how this document benefits you.

\section{Recommended Citation}

Rutheford B. Campbell, Jr., Bumping Along the Bottom: Abandoned Principles and Failed Fiduciary Standards in Uniform Partnership and LLC Statutes, 96 Ky. L.J. 163 (2008)

This Article is brought to you for free and open access by the Law Faculty Publications at UKnowledge. It has been accepted for inclusion in Law Faculty Scholarly Articles by an authorized administrator of UKnowledge. For more information, please contact UKnowledge@lsv.uky.edu. 
Bumping Along the Bottom: Abandoned Principles and Failed Fiduciary Standards in Uniform Partnership and LLC Statutes

\section{Notes/Citation Information}

Kentucky Law Journal, Vol. 96, No. 2 (2007-2008), pp. 163-195 


\section{Kentucky Law Joumal}

\begin{tabular}{lll}
\hline VOLUME 96 & $2007-2008$ & NUMBER 2 \\
\hline
\end{tabular}

A R T I C L E S

\section{Bumping Along the Bottom: ${ }^{1}$ Abandoned Principles and Failed Fiduciary Standards in Uniform Partnership and LLC Statutes}

Rutheford B Campbell, Jr. ${ }^{2}$

Table of Contents

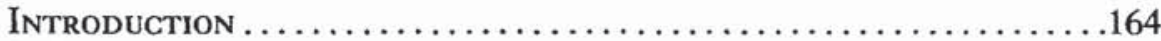

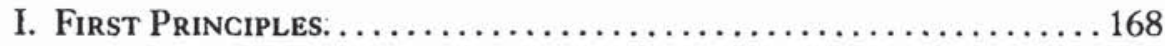

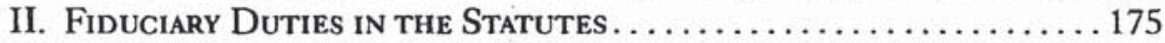

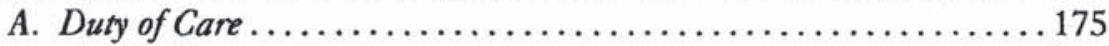

1. The Standard ................................... 175

2. Opting out of the Duty of Care ........................

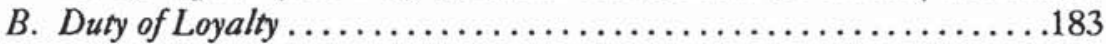

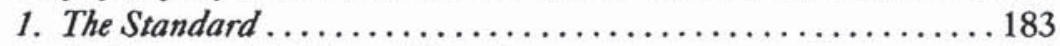

2. Opting out of the Duty of Loyalty ....................

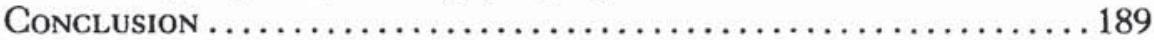

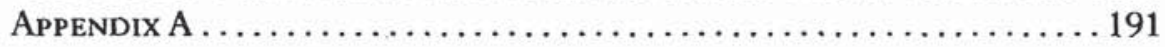

I In his famous article, the late Professor William Cary used the bottom as a metaphor for lax, pro-management fiduciary duties. The thesis of his article was that Delaware, in order to attract corporations to incorporate in the state, established a regime of corporate laws that offered little protection for shareholders, while allowing managers the opportunity to operate without effective monitoring or limitations on their self-serving activities. William L. Cary, Federalism and Corporate Law: Reflections Upon Delaware, 83 YALE L.J. 663 (1974). His article generated an intense and interesting debate that is well captured in WILLIAM L. CARY \& Melvin Aron Eisenberg, Cases and Materials On Corporations 125-32 (7th ed. 1995).

2 Rutheford B Campbell, Jr. is the Alumni Professor of Law at the University of Kentucky College of Law.

My thanks to Bill Callison, Tom Rutledge and Allan Vestal, who offered comments on this article. 


\section{INTRODUCTION}

$\mathrm{O}$ VER the last decade or so, the National Conference of Commissioners on Uniform State Laws (NCCUSL) has promulgated a series of uniform laws dealing with unincorporated business entities. ${ }^{3}$ The Uniform Partnership Act (1997) (RUPA), ${ }^{4}$ the Uniform Limited Partnership Act (2001) (ULPA (2001)), ${ }^{5}$ and the Uniform Limited Liability Company Act (1996) (ULLCA) ${ }^{6}$ are recent and important iterations of these uniform laws. One or more of these Acts have been adopted in many states ${ }^{7}$ and are certain to garner additional adoptions in the coming years. ${ }^{8}$

3 The National Conference of Commissioners on Uniform State Laws (NCCUSL) is composed of Commissioners from all the states, the District of Columbia, and Puerto Rico. Commissioners are usually appointed by their respective state governors or legislatures. When NCCUSL decides to consider a particular subject such as, in our case, laws governing partnerships, limited partnerships or limited liability companies, it will appoint a Special Committee of Commissioners to prepare the various drafts of the particular act, which are then submitted to the Commissioners for review and recommendations. Once approved by the Commissioners, the proposed uniform act may be submitted for consideration by the ABA. See, 6 U.L.A. III-IV (pL. I) (2001); National Conference of Commissioners on Uniform State Laws 2006-2007 Reference Book, at 9.

4 Unif. P'SHIP Acr, 6 U. L. A. 58-274 (pt. I) (1997).

5 UNif. LTD. P'ship Act, 6A U. L. A. 9-123 (2001).

6 Unif. LTD. LiAB. Co. Act, 6A U. L. A. 560-650 (1996). A new version of a limited liability company act, the Revised Uniform Limited Liability Company Act (RULLCA), has been approved by NCCUSL and awaits final approval by the American Bar Association. That Act makes significant changes in the fiduciary duties of managers as compared to those duties in RUPA and ULLCA. The fiduciary duty standards of RULLCA are the subject of a forthcoming article by the author, The New Fiduciary Standards Under the Revised Uniform Limited Liability Company Aa: We Just Can't Seem to Get It Right. No state has yet adopted the RULLCA.

7 As of December 28, 2007, NCCUSL's website, www.nccusl.org, reported the following numbers of adoptions by states and territories in the United States. Thirty-five states and territories had adopted RUPA. Uniform Law Commissioners, http://www.nccusl.org/ Update/uniformact_factsheets/uniformacts-fs-upa9497.asp (last visited Dec. 28, 2007). Fourteen states had adopted ULPA (2001). Uniform Law Commissioners, http://www.nccusl. org/Update/uniformact_factsheets/uniformacts-fs-ulpa.asp (last visited Dec. 28, 2007). Nine states and territories had adopted ULLCA. Uniform Law Commissioners, http://www.nccusl. org/Update/uniformact_factsheets/uniformacts-fs-ullca.asp (last visited Dec. 28, 2007).

8 For example, during its 2006 legislative session, Kentucky adopted RUPA, Ky. Rev. Stat. ANN. §§ 362.1-101-362.1-1205 (West 2006), and ULPA (2001), Ky. Rev. Stat, ANN. §§ 362.2-102-362.2-1207 (West 2006). 
Each of the Acts contains provisions that prescribe the fiduciary duties of the entity's managers. ${ }^{9}$ The managers'10 duties are articulated in the familiar terms of duties of care and duties of loyalty and are largely default rules that are subject to opt out rights by the parties. The fiduciary duty provisions are essentially identical in all three of the Acts. ${ }^{\prime \prime}$

The fiduciary duties in these Acts are to a significant degree unsatisfactory. In various and important ways, they promote outcomes that are unfair and inefficient.

The duties of care and loyalty in RUPA, ULPA (2001) and ULLCA are excessively pro-management. They seem designed to promote managers' pecuniary interests in achieving an inefficient and unfair bargain with the entity's investors regarding the nature of managers' fiduciary duties. ${ }^{12}$ The statutory standards themselves are overly lax and limited. ${ }^{13}$ The standards offer inadequate protection for the legitimate interests and expectations of investors regarding the standards of care and loyalty that they are due from their managers. The opt out provisions in the Acts offer managers the opportunity to exacerbate this bad situation by further exploiting informational asymmetries and thus capturing for themselves additional pecuniary gains by constructing an even more inefficient and unfair bargain with their investors. ${ }^{14}$

The fundamental problem with the Acts' fiduciary duty standards is that they abandon widely-accepted and morally and economically pleas-

9 Before the adoption of the uniform acts, the fiduciary duties of managers of unincorporated business entities were promulgated and interpreted by courts through the common law process, principally in the context of general partnership law. The 1914 version of the Uniform Partnership Act, for example, had only one provision that imposed any significant fiduciary duties on persons managing general partnerships: UNIF. P'sHIP Act § 2I, 6 U. L. A. 194 (pt. II) (1914) (amended 1997) (obligating partners to account for profits derived by her or him from transactions with the partnership). As a result, fiduciary duties under the UPA largely developed through the common law; e.g., Marsh v. Gentry, 642 S.W.2d 574 (Ky. 1982); Meinhard v. Salmon, 164 N.E. 545 (N.Y. 1928).

10 Throughout this paper, I use the term manager to mean the one person who exercises management control over the entity. In a partnership or limited partnership, the person performing the management function will likely be one or more of the general partners. In a manager-managed LLC, the person performing the management function will likely be a manager, while in a member-managed LLC, the person performing the management function will likely be one or more of the LLC's members.

11 In APPENDIX A to this article, I reproduce in full the relevant fiduciary duty provisions from RUPA, ULPA (200I) and ULLCA. I also reproduce provisions from each of the Acts that allow parties to opt out of the statutory fiduciary duties.

12 For a discussion of the ability and pecuniary incentive of managers to construct an inefficient and unfair bargain with investors, see infra notes 50-52, 57-59 and accompanying text.

13 See infra notes $41-48$ and accompanying text (describing the overly lax standard of care), and notes 66-78 and accompanying text (describing the overly limited duty of loyalty).

14 See infra notes $53-65,79-86$ and accompanying text. 
ing principles. ${ }^{15}$ These abandoned principles are founded on consent and provide, for example, that in the absence of third-party effects, parties-in this case managers and investors-should be permitted to fashion their own arrangements with one another and that the rules of society should promote outcomes consistent with this idea.

Measured against the principles of actual or inferred consent, the fiduciary standards in the Acts fail to pass muster. It is difficult to imagine that most investors, if fully informed, would consent to default standards of care and loyalty as lax and limited as those contained in the Acts. It is even more difficult to imagine that investors, if fully informed, would consent to even lower standards that are permissible under the opt out provisions of the Acts. In short, the fiduciary standards contained in the Acts promote outcomes in which parties, who are less than fully informed, are saddled with terms that are not fully priced.

There are explanations that one might offer for the lax, limited, and unduly pro-management fiduciary standards in the Acts. Bill Callison, for example, has suggested that the fiduciary standards coming from NCCUSL sometimes evolve without any serious thought ${ }^{16}$ and are compromised by drafting hubris. ${ }^{17}$ My own view, however, is that the failure of these uniform acts to establish appropriate fiduciary standards is better explained by reference to public choice theory or a capture analysis.

Public choice theory ${ }^{18}$ (also called interest group theory ${ }^{19}$ ) offers an economic explanation for the extent to which interested groups are able to influence the outcome of legislative action. ${ }^{20}$ The theory posits that a smaller, cohesive interest group will have more influence on the outcome of legisla-

15 For a discussion of these principles, see infra notes 24-33 and accompanying text.

16 J. William Callison, "The Law Does Not Perfectly Comprehend ...": The Inadequacy of the Gross Negligence Duty of Care Standard in Unincorporated Business Organizations, 94 Kr. L.J. 45I, $452(2005-06)$.

17 Id. at 484 .

18 Much has been written about public choice theory. See, e.g., Daniel A. Farber \& Phillip Frickey, The Jurisprudence of Public Choice, 65 Tex. L. Rev. 873, 873-901 (1987); Jonathan R. Macey, Promoting Public-Regarding Legislation Through Statutory Interpretation: An Interest Group Model, 86 Colum. L. Rev. 223, 227-33 (1986).

I9 Macey, supra note 18 , at 224, n.6.

20 See, e.g., William W. Landes \& Richard A. Posner, The Independent Judiciary in an Interest Group Perspective, I 8 J.L. \& Econ. 875, 877 (1975):

In the economists' version of the interest-group theory of government, legislation is supplied to groups or coalitions that outbid rival seekers of favorable legislation. The price that the winning group bids is determined both by the value of legislative protection to the group's members and the group's ability to overcome the free-rider problems that plague coalitions. Payments take the form of campaign contributions, votes, implicit promises of future favors, and sometimes outright bribes. In short, legislation is "sold" by the legislature and "bought" by the beneficiaries of the legislation. 
tion than a competing larger, diffuse group, even though the larger group as a whole may value the legislation more than the small group as a whole.

At first blush this theory seems problematic at best, since a group that stands to gain the most in total seemingly could expend the most resources to obtain their preferred legislative rule. Public choice theory, however, explains this counterintuitive outcome by reference to the problems and expense of collective action. It simply costs more to form and manage a large group than it does a small group. Free rider problems ${ }^{21}$ also increase with the size of the group. Members of large groups become more likely to hang back, hoping others in the group will commit sufficient resources to obtain the preferred outcome, enabling the non-participants to free ride on the contributions and work of the participating members of the group.

These collective action problems can explain why it is nearly impossible for investors in unincorporated businesses to obtain, for example, their preferred standard of care for managers in the uniform acts. The investors' group would consist of all investors in all unincorporated businesses, which is obviously a huge group. Concerted action by this group with regard to rules promulgated by NCCUSL or adopted by state legislatures involves overwhelming transaction costs and free rider problems. ${ }^{22}$

Managers of unincorporated business entities, while certainly amounting to a huge group, may have another way to achieve their preferred outcome with regard to fiduciary duties in uniform acts. Drafters of society's rules may be captured by particular interest groups. In its mildest formand that is the limit of what I suggest here-this only means that drafters' professional interests and life experiences cause rule-makers to align with the preferences of managers. This alignment may result from the fact that managers (as opposed to investors) are the most likely clients of the drafters. This may suggest that the most apparent basis for a bias may be economic interests, since rational drafters may conclude that they can enhance

See also, Michael T. Hayes, Lobbyists and Legislators: A Theory of Political Markets 69-70 (Rutgers University Press 1981) ("Members of the mass public will generally find it irrational to obtain the information necessary to identify their interest on any given issue and moreover will be ill-equipped to interpret any information they do obtain"); Farber \& Frickey, supra note 18, at 892; Macey, supra note 18, at 229-32.

21 See, e.g., Farber \& Frickey, supra note 18, at 892 ("The 'free rider' problem suggests that it should be nearly impossible to organize large groups of individuals to seek broadly dispersed public goods. Instead, political activity should be dominated by small groups of individuals seeking to benefit themselves, usually at the public expense").

22 To illuminate this point, assume, arguendo, that the standard of care preferred by investors as a group is negligence. Identifying all or even most of the group seems impossible, and communication among those members that are identified is expensive. Members may also individually not be willing to pay much to achieve a negligence standard. Finally each member has an interest in hanging back, hoping that others will make the expenditures necessary to get the preferred standard, which will then allow them to free ride-to enjoy the preferred result without expending any resources. 
their client base ${ }^{23}$ by acting in ways that please managers. It may well be, however, that the more effective capture is of the minds and hearts of drafters by non-economic means. My own experience suggests that the views and biases of lawyers tend to drift toward those of the clients they serve over time. It is hard for me to imagine that my representation of the interests of managers, which is the group I most represented in practice, did not increase the probability that my views of what amounts to an appropriate fiduciary standard would be bent toward the preferences of my clients.

Whatever may be the reason, the fiduciary duties in the uniform acts for unincorporated business entities are substantially flawed by a pro-management bias. This article, therefore, makes the case for rethinking these important duties and offers a number of first principles as bases from which to revise the fiduciary duties respecting partnerships, limited partnerships, and limited liability companies. The principles I offer are simple and generally uncontroversial. The principles illuminate the failure of the present fiduciary standards in RUPA, ULPA (2001) and ULLCA and offer guidance toward better fiduciary duty rules that promote fair and efficient outcomes.

In Part I of this article, I articulate my first principles, which should be the bases for fair and efficient fiduciary duty rules. In Part II, I use those principles to demonstrate the failings of the fiduciary standards presently found in the uniform acts and to support the revisions that I offer for those fiduciary standards.

\section{First PRINCIPLES}

Fiduciary duties applicable to non-corporate business entities should promote fair and efficient outcomes and thus should be founded on principles consistent with these worthy goals.

I offer the following first principles as bases from which to proceed to such pleasing outcomes. The principles are simple, well-known and rest comfortably on the morally and economically attractive notion of consent. In short, these are principles over which there is wide agreement.

Perhaps most fundamental is the principle that managers and investors in unincorporated entities, if they are able, ought to be permitted to shape the terms of their arrangements between or among themselves, provided that their arrangements do not generate material adverse third-party effects. ${ }^{24}$ The moral and economic right of parties, in the absence of third-

23 Academics on NCCUSL Committees may also be perceived as subject to similar bases for a pro-manager bias. Academics may continue to have private clients. Also, managers (or entities they control) may make donations to academic institutions.

24 Third-party effects are also sometimes referred to as externalities. The term means economic impact to some person not a party to the transaction. See, e.g., Richard A. PoSNER, Economic Analysis of Law 71 (6th ed. 2003) (hereinafter Posner, Economic Analysis) 
party effects, to pursue their own preferences is supported by their own consent and thus can be traced to both Kantian moral theory and utilitarianism. $^{25}$ Allowing parties to set their own terms is respectful of the autonomy of rational beings (broadly, a Kantian notion) and promotes the maximization of overall utility or happiness (a utilitarian goal). ${ }^{26}$

It is difficult to identify any material third-party effects generated when a manager of an unincorporated business entity and the entity's owners agree on the terms of the manager's employment, including the nature and extent of that manager's fiduciary duties. ${ }^{27}$

One might imagine, for example, a case in which a manager and the owners of a partnership or an LLC are bargaining over the manager's duty of care and whether the standard should be negligence or gross negligence. Whichever of the standards is agreed upon by the parties, the choice affects only the parties, and they are able to consent to and price the terms of their arrangement. So, if the agreed-upon standard is negligence, the owners get better service, but have to pay the manager a higher fee. If, instead, the standard they agree to is gross negligence, the owners get somewhat less careful management, but pay less for it. In either case, the parties have consented and priced the outcomes, and neither choice seems in any way materially to affect other persons. Whether the parties choose negligence or, perhaps, opt instead for a gross negligence standard, it is a private decision between the parties without material third-party effects and thus should be respected by society. ${ }^{28}$

(defining externalities in the context of property law matters).

25 In Richard A. Posner, The Ethical and Political Basis of the Efficiency Norm in Common Law Adjudication, 8 Hofstra L. Rev. 487 (1980), Judge Posner offers a moral defense for the pursuit of economic efficiency based essentially on the consent of the parties and thus argues that pursuing economic efficiency "will produce an ethically attractive combination of happiness, of rights (to liberty and property), and of sharing with less fortunate members of society." Id. at 487 .

26 See Jeffrie G. Murphy \& Jules L. Coleman, Philosophy of Law $70-82$ (1990) (discussing and comparing Utilitarianism and Kantianism); see also, Jefrrie G. MURPHY, KANT: ThE Philosophy OF Right (Macmillan 1970) (discussing the philosophy and writings of Kant). For a more extensive discussion of Utilitarianism, see J.J.C. SMarT \& B. Williams, Utilitarianism (Cambridge University Press 1973) and H.L.A. Hart, Between Utility and Rights, 79 Colum. L. Rev. 828 (1979). The foundations for utilitarianism are found in Jeremy Bentham, AN Introduction to the Principles of Morals and Legislation (J.H. Burns \& H.L.A. Hart eds., Athlone Press 1970) (1789) and John Stuart Mill, Utilitarianism (E.P. Dutton and Co., Inc. 1951) (1863).

27 See, e.g., Mark J. Loewenstein, Fiduciary Duties and Unincorporated Business Entities: in Defense of the Manifestly Unreasonably Standard, Univ. of Colo. Law Legal Studies Research Paper No. 06-06, at 3, available at http://papers.ssm.com/sol3/papers.cfm?abstract_id=8932 I3 ("no third parties are adversely affected by their deal" (quoting J. Dennis Hynes, Freedom of Contract, Fiduciary Duties, and Partnerships: The Bargain Principle and the Law of Agency, 54 WASH. \& LeE L. Rev. 439, 443 (1997))).

28 Perhaps one might argue that a gross negligence standard has third-party effects, since it increases the likelihood of the entity's failure, which then might harm non-owner 
In many situations, however, high transaction costs make it impossible or inefficient for parties to bargain, and in such cases efficiency may be promoted by an appropriately crafted societal rule. Search costs, negotiation costs, free rider problems, and bilateral monopolies are examples of factors that may generate transaction costs when parties attempt to bargain with one another. ${ }^{29}$ These transaction costs may in some cases exceed the value created by the transaction, and, obviously in such instances the transaction, although assumed to be efficient, will not occur. ${ }^{30}$ Even where the transaction will occur, a societal rule that mimics the arrangement that most of the parties would select in most cases may promote efficiency by eliminating the need of the parties to bargain and thereby reduce transaction costs. ${ }^{31}$

The next principle, therefore, is that in instances where constructing their own terms is inefficient or impossible for parties, society ought to enact broadly applicable rules consistent with those that the parties in most circumstances would select, if they were able to bargain. This amounts to a natural extension of the principle that parties, in the absence of third-party effects, should be permitted to construct their own terms to govern their private transactions.

constituencies, for example creditors. Not only is this a quite attenuated argument, but also it is not at all clear creditors are actually harmed in any material way. Creditors can fully protect themselves by contract and price. So, for example, a lender to an LLC with a gross negligence standard, if it faces increased risk, can insist on protective covenants or a higher price for its loan. In extending credit, of course, fully informed creditors always price the risk of the economic failure of the entity to which they loan money. Banks, for example, demand more interest for loans that have higher default risk.

29 A good example outside the business entity area is pollution. The parties impacted by pollution are, on the one hand, the polluter, and, on the other, the many people adversely impacted by the effects of the pollution. Bargaining between these parties is impossible because it is functionally impossible for the polluter to identify and bargain with all the parties adversely impacted by pollution. Even if it were possible for the parties to identify each other, each of the parties adversely affected by the pollution would be inclined not to bargain with polluter in hopes that all the other adversely affected parties would arrive at a solution with the polluter that is pleasing to the particular non-bargaining party, thus relieving him of the costs and inconvenience of bargaining himself. For an excellent discussion of transaction costs (i.e., free rider problems, bilateral monopolies, etc.) in the context of pollution, see Posner, Economic Analysis, supra note 24, at 60-62.

30 Consider the following simple example. Assume $A$ has an antique table that he values at $\$ 10,000$ and that $B$ values at $\$ 11,000$. If transaction costs (perhaps the costs of hiring a lawyer to negotiate the transaction and draft a contract governing the terms of the sale) amount to $\$ \mathrm{I}, 100$, the sale will not occur, even though B values the table more than $\mathrm{A}$. See Posner, ECONOMic ANalysis, supra note 24, at 61 ("If transactions costs are ... higher than the value of the transaction ... they won't be incurred; the parties will be better off foregoing the transaction").

31 Assume that ten sets of parties would engage in a particular transaction and that without a societal rule governing the terms of the transaction, transaction costs would amount to $\$ 10$ per transaction, or $\$ 100$ total. If society can enact a rule that approximates the terms the parties would select, parties will no longer have to expend \$10 on each transaction, arriving at efficient outcomes with fewer expenditures. 
These principles suggest strongly that society should enact fiduciary duty rules governing unincorporated entities and that those duties should amount to those that most parties in most situations would agree upon. If, for example, most managers and investors in most unincorporated business entities would agree on a negligence standard of care for managers, a broadly applicable societal rule establishing negligence as the standard of care enhances the probability of efficiency in cases where transaction costs are so high as to prevent bargaining. Even in cases where bargaining over fiduciary standards is possible, a rule that mimics the preferences of the parties in most cases enhances efficiency by relieving those parties of the need to bargain.

Another principle, which should be apparent from the prior discussion, is that, ideally, society's rules respecting fiduciary duties in unincorporated entities should be default rules. Default rules preserve the ability of parties to reach efficient outcomes in instances in which society's generally efficient arrangements do not satisfy the particular parties' preferences. Default rules, therefore, are properly viewed as ameliorating the probability of inefficient outcomes resulting from society's rules.

Certain conditions must exist for society's default rules to work at their best. First, society's default rule itself must be intelligible. Obviously, in order to choose between accepting society's default rule or remaking the default rule, a party must understand the default rule. Without an understanding of society's rule, true consent is impossible, and a party may, for example, eschew exercising the right to construct a new rule that suits her preference because she, mistakenly, believes that the default rule meets her preferences. ${ }^{32}$

Next, the process for remaking, or opting out of, the default rules should be inexpensive. If, for example, society mandates an elaborate opt out process that costs the parties 10 to exercise and the parties' total gain from remaking the inefficient default rule is only 8 , the parties will accept society's inefficient default rule. ${ }^{33}$

The last condition necessary for opt out provisions to achieve maximum efficiency is that the parties must be fully informed. If asymmetry

32 Assume, for example, that the statutory default standard of care for a manager of an unincorporated business entity is actually gross negligence, but that the statute defines the standard of care in a manner that leads an investor to believe the standard is negligence. If an investor preferring negligence accedes to the default standard, the outcome may be ineffcient, since it may be likely that if the investor were fully informed (i.e., understood the actual default standard), the parties would have opted out of the default standard, and the agreement between the investor and the manager would have been struck at negligence.

Unintelligible standards may also generate high transaction costs as the parties, likely with help from lawyers, attempt to sort out the meaning of the default standard. Later, managers will have more uncertainty about the propriety of their actions, again generating unnecessary costs as they attempt to meet the requirements of unclear rules.

33 This is the same point made previously. See supra note 30 and accompanying text. 
of information about the terms of the opt out provision enables one party to fool the other regarding the actual terms of the remade arrangement, the remade arrangement may not be efficient. It may not be the term that would have been agreed upon, if both parties had been fully informed. This, of course, is the flip side of the point made above, which was that consent regarding opting out requires an understanding of the default rule. Here the point is that consent also requires an understanding of the remade rule as well. In short, consent and thus fairness and efficiency require parties to be fully informed.

This, then, leads to the final of my first principles. If most parties opt out of a societal rule that for them is efficient and into a remade rule that for them is inefficient, society's rule should be mandatory.

While this statement may at first seem silly, since an efficient rule for the parties is one that they prefer and it is therefore difficult to imagine why such parties would abandon the preferred rule, it relates back to the point made immediately above regarding asymmetry of information. Assume that society rules impose a 6 month warranty of merchantability on all washing machines and that reflects the arrangement that would be agreed upon by the parties in $98 \%$ of all washing machine sales. If the warranty is a default rule, however, manufacturers may be able to price their washing machines as if the warranty were in place, while opting out of the warranty. This could be accomplished by burying the opt out term in a purchase contract, which, one might assume, involves consumers who will be unable or unwilling to plow through the fine print. The result of an unfettered opt out right in such a case, therefore, is an outcome that is both inefficient and unfair. It is inefficient since it is not the agreement that the large majority of the parties would agree to, if they were fully informed. It is unfair because consumers are paying for the warranty but not receiving it.

These facts suggest that a mandatory rule imposing the warranty of merchantability is appropriate in this situation. Although under the mandatory rule, $2 \%$ of all transactions would involve an inefficient outcome, $98 \%$ would involve an efficient outcome. Professor Richard Booth ${ }^{34}$ and

34 Richard A. Booth, Fiduciary Duty Contract and Warver in Partnerships and Limited Liability Companies, I J. Small \& EMERging Bus. L. 55, 64 (1997). Although clearly favoring LLC fiduciary rules that permit generous opting out, Professor Booth defends the limitations ULLCA imposes on the complete opting out of fiduciary duties. He concludes that permitting parties an unlimited right to opt out of the ULLCA's fiduciary standards "is too easy." Id. "A statute that allows for total waiver would likely undercut serious bargaining between the parties .... It would allow the more informed party simply to insist on a total waiver without specifying the nature of the conflict expected." Id. at 61. His position seems firmly rooted in the idea that sound economic theory requires mandatory terms when it is likely that sharp operators will exploit strategic and informational advantages in ways that permit them to construct inefficient trades in most cases. An efficient societal mandatory rule is the best solution in that case. 
Professor Mark Loewenstein ${ }^{35}$ have persuasively argued similar points in connection with a defense of a mandatory core of fiduciary duties in unincorporated associations.

This analysis becomes specifically relevant later in this paper when we evaluate the statutory opt out provisions in the ULLCA, RUPA and ULPA (2001), since managers of unincorporated business entities, similar to the above example involving manufacturers of washing machines, often have both the incentive and opportunity to exploit information asymmetries in opting out. ${ }^{36}$

The principles articulated in this portion of the paper generate little theoretical controversy or disagreement, due in large part to the fact that the principles are based on the morally attractive notion of consent. If two parties knowingly enter into a transaction that has no adverse effects on any other person, it is quite difficult to raise any moral objection to the transaction. The benefit of the transaction to the parties is proven by their consent and the absence of harm to anyone else offers strong moral support for allowing the transaction to go forward. Even the most vigorous advocates of competing positions ${ }^{37}$ seem in agreement on this fundamental point. ${ }^{38}$

The disagreement between contractarians and fiduciarians or liberals and conservatives is largely about the facts. Thus, for example, while near-

35 Loewenstein, supra note 27 , at 28 ("the relevant operating or partnership agreement may be very long and complex. Terms that relate to fiduciary duties may not be collected in one section; instead, terms ... may appear in various sections dealing with management, distributions, repurchase of units, etc."). Later he says: "the investor may not, in fact, be fully informed or sufficiently sophisticated ...." Id. at 29.

36 See infra notes $57-65,83-86$ and accompanying text.

37 Dean Allan Vestal and Professor Larry Ribstein are two of the most forceful and persuasive advocates of the compering positions that may be referred to, respectively, as fiduciarians and contractarians. Compare the fiduciarian views expressed in Allan W. Vestal, Fundamental Contractarian Error in the Revised Uniform Parnership Act of 1992, 73 B.U. L. Rev. 523,524 (1993) ("I conclude that the contractarian error is so basic to the Revised [Uniform Partnership] Act, and the deleterious effects of the error are so profound, that the Conference should withdraw the Revised Act, rework it to conform to the fiduciary world view, and only then repromulgate it and recommend its adoption by the states"), with the contractarian views in Larry E. Ribstein, The Revised Uniform Partnership Act: Not Ready for Prime Time, 49 Bus. LAw. $45,5^{2}$ (1993) (using contractarian arguments to criticize the fiduciary duty rules of RUPA as "seriously misguided").

38 Consider, for example, an article written during the debate over the Revised Uniform Partnership Act. Dean Vestal describes the fiduciarian approach as one in which partners "are free to pursue their individual self-interest at the expense of the collective only in situations where cither the partners clearly understand ex ante that the collective interest might be subordinated, or where the partner... obtains the informed consent of the other partners to do so." Vestal supra note 37 , at 524 (emphasis added). Dean Vestal articulates the contractarian view as one in which, "partners always are free to advance their own self-interest [through contract] . . unless they specifically agree to the contrary." Id. at 523-24 (emphasis added). The quote from Dean Vestal's article accurately suggests that both sides in the debate appreciate the importance of consent and the moral attractiveness of society's permitting parties to shape their own fiduciary duties. 
ly everyone would agree with the principle that society's fiduciary duty rule should be the rule that most parties would agree upon, there likely will be a spirited debate about the factual matter of what rule the parties would choose. Regarding the matter of the standard of care imposed on managers of unincorporated business entities, for example, contractarians may argue that if investors and managers were able to bargain, most bargains would be struck around a very lax standard, perhaps limiting managers fiduciary duty of care only to forbid managerial acts that amount to intentional misconduct. Fiduciarians, on the other hand, may imagine that the facts are entirely different and thus argue that parties would undoubtedly agree upon a tough standard of care, such as negligence. ${ }^{39}$

Factual disagreements may also arise around the last of my first principles, where contractarians may argue against the imposition of any mandatory limitation on the right of parties to fashion the terms of their agreement. They may base this argument on their factual reckoning that the risk of exploitation of informational asymmetries is low or non-existent, and thus the parties are in such cases fully able to protect themselves by contract. Fiduciarians, on the other hand, may see the facts as involving pervasive and significant informational asymmetries that are exploited by managers at the expense of investors in nearly all cases.

It is helpful to realize that the essence of the disagreement over the appropriate shape of fiduciary duties is more about the facts than about prin-

39 Fiduciarians and contractarians may have views of the facts in particular instances and indeed of the world that seem vastly different. A vivid example of this can be found in an earlier debate over the employment at will doctrine. An employment at will is an arrangement which can be terminated without cause by either the employer or the employee. On what I would consider the contractarian side of the debate, Richard Epstein argued in favor of the employment at will doctrine as being efficient. Part of his argument was based on his factual assumption that workers are fully able to take care of themselves by shaping contracts that would meet their preferences with regard to job protection. In Epstein's view, "we are dealing with the routine stuff of ordinary life; people who are competent enough to marry, vore, and pray are not unable to protect themselves in their day-to-day business transactions." He found no "reason to believe that [employment] ... contracts are marred by misapprehensions, since employers and employees know the footing on which they have contracted." Richard Epstein, In Defense of the Contract at Will, 5 I U. CHI. L. Rev. 947, 954-55 (1984).

Representing what I would characterize as the fiduciarian side of the debate, Professor Clyde Summers had an extremely different view of the facts in regard to employment at will contracts. Summers' research enabled him to conclude that in "tens of thousands of [employee] discipline cases, ... nearly half [involved] ... instances of injustice." Clyde Summers, Individual Protection Against Unjust Dismissal: Time for a Statute, 62 VA. L. Rev. 481, 532 (1976). He was also convinced by research that showed more than half of all discharge cases resulted in reinstatement of the dismissed employee. Id.

These views, of course, are based on dramatically different assessments of the facts. Epstein is of the opinion that workers can and do work out suitable terms. Summers takes the opposing position regarding workers' ability to protect themselves against overreaching by employers. 
ciples. This recognition sharpens and focuses the debate. It forces those of us who are engaged in the polemic over the appropriate nature of fiduciary duties to articulate and defend factual assumptions that underlie our rules. It also may encourage empirical work that can shed light on the real facts and thus lead society into rules that are more efficient and fair.

\section{Fiduciary Duties in the Statutes}

RUPA, ULLCA and ULPA (2001) all adopt the same construct of dividing fiduciary duties into the duty of care and the duty of loyalty, articulating standards for both loyalty and care obligations, and permitting the parties to a significant degree - but not entirely - to opt out of the statutory standards for duty of care and duty of loyalty. The three statutes also contain essentially the same substantive standards for duty of care and duty of loyalty. ${ }^{40}$

Measured against the principles described in Part I of this paper, the fiduciary duty rules in these uniform acts are badly flawed and thus likely to lead to unfair and inefficient outcomes.

\section{A. Duty of Care}

1. The Standard.-RUPA, ULLCA and ULPA (2001) all opt for a gross negligence standard of care. ${ }^{41}$ A gross negligence standard amounts to a significantly more relaxed standard of care than a negligence standard. Under a negligence standard, managers would breach their duty by a failure to use reasonable care..$^{42}$ Under the more relaxed gross negligence standard adopted by the three uniform acts, however, managers breach their duty of care only if their actions are so stupid and careless as to amount to a gross or extreme deviation from reasonable care. ${ }^{43}$

40 The fiduciary duty sections and the opt-out sections from each of the three uniform acts are reproduced in APPENDix A infra.

41 See Appendix A infra. Not all states adopting the uniform acts have accepted the gross negligence standard of care. In 2006, Kentucky, for example, adopted both RUPA and ULPA (2001) and in both cases chose to incorporate a negligence standard of care in lieu of the Uniform Acts' gross negligence standard. See Kr. Rev. Stat. ANN. § 362.1-404(3) (West 2007) (partnership duty of care); Ky. Rev. StıT. ANN. § 362.2-408(3) (West 2007) (limited partnership duty of care).

42 See, e.g., Restatement (Second) of Torts $\$ 282$ (1963) ("negligence is conduct which falls below the standard established by law for the protection of others against unreasonable risk of harm").

43 Although there is less than unanimity about the definition of gross negligence, gross negligence always involves a significant deviation from a standard of reasonable care. See, e.g., Restatement (Third) of ToRTs $\$ 2$, cmt. a (Tentative Draft No. I, 2001) (requiring negligence that is "especially bad"); W. Page Keeton, et al., Prosser \& Keeton on the Law OF TORTs § 34, at 21 1-12 (W. Page Keeton ed., 5th ed. 1984) ("very great negligence"). An example I often use with my class is as follows: In a 35 mile per hour zone, it is negligence to 
Gross negligence as a standard of care lacks quantitative precision. Because it is a standard articulated in general terms, its applicability in some cases will be uncertain. This inherent ambiguity is troubling to some. ${ }^{44}$

This marginal vagueness, however, is not the most troubling aspect of the gross negligence standard of care found in the uniform acts. ${ }^{45}$ The much more serious problem is that gross negligence amounts to the wrong standard. It promotes outcomes that are inefficient and unfair. ${ }^{46}$

If one returns to the principles in Part I of this paper, ${ }^{47}$ a gross negligence standard is inconsistent with the principle that society's default rule should be the rule that most parties in most cases would select. It seems highly unlikely that fully informed owners and managers of unincorporated business entities would in most cases select gross negligence as a standard of care, since such a lax standard provides no incentive for managers to act reasonably. Indeed, a gross negligence standard actually generates an incentive on the part of managers to act unreasonably or negligently with regard to their obligations to owners. One can assume that it takes more time and energy for a manager to act reasonably than it does for the manager merely to refrain from acting extremely unreasonably. Logically, therefore, one may see managers as sacrificing their valued leisure time in order to move the quality of their management from the not-extremely unreasonable standard (gross negligence) to the not-unreasonable standard (negli-

drive 38 miles per hour and gross negligence to drive 60 .

44 See, e.g., William T. Quillen, Trans Union, Business Judgment, and Neutral Principles, to DEL. J. CORP. L. 465, 497-98 ( 1985 ) ("The concept of 'gross negligence' has been expressly rejected by the better tort scholarship as practically meaningless. Therefore its recent adoption in corporate law would appear, in some respects, to be an analytical step backwards").

45 Standards of care designed for broad application must often, out of necessity, be articulated in a general fashion. Consider, for example, an obligation imposed by tort law to operate an automobile in a reasonable fashion. While such a rule may be somewhat vague around the margin, it is impractical (impossible?) for society to enact the literally thousands of small rules that are captured by the reasonableness rule (e.g., driving speed in rain, in one inch of snow, when crowds appear along the side of the road, etc.; the obligation to set a parking brake on a flat grade, on a $2 \%$ incline, when pedestrians are present or when no pedestrians are present but valuable property is present). The economic cost of vagueness may be offset by the savings in not enacting, enforcing, etc. many rules.

46 In Donald J. Weidner, Three Policy Decisions Animate Revision of Uniform Partnership Act, 46 Bus. Law. 427, 464-69 (1991), Dean Weidner provides both an interesting historical perspective on partners' standard of care and an explication of the debate and arguments that occurred in connection with the adoption of RUPA's standard of care. The strongest-but yet unconvincing-argument recounted by Dean Weidner in favor of a lax, gross negligence standard of care is an insurance-based argument. If, as the argument goes, all partners are equally engaged in the management of the partnership and thus equally likely to harm the interests of the partnership by their negligent act, the partners rationally would agree not to be individually liable for negligence, but would instead agree to share negligence induced losses among the partners as a group. In such cases, sharing the negligence losses by opting into a gross negligence standard of care becomes a form of self-insurance. Id. at 468 .

47 See supra notes 24-39 and accompanying text. 
gence). It is hard to imagine that most investors would be willing to accept an investment that offers managers such incentives for poor management.

Imagine, for example, a situation in which managers, putting together a deal, tell investors that they, as managers, are not required to pursue the best interests of the owners with a reasonable level of care and skill but that, instead, they are permitted-actually, even encouraged by the structure of their incentives - to act unreasonably. It is hard to believe that most investors would make such an investment. It seems much more likely that investors would in such a case search for an alternate investment that had a more favorable management contract and would be willing to pay the additional management costs necessary to promote a reasonable level of care and skill in the management of their investment. In the competitive capital and management markets, I find it nearly impossible to imagine that investors and managers, assuming full information and the ability to bargain with one another, would in most cases opt into a gross negligence standard of care.

I admit, indeed I emphasize, that my disagreement with the uniform statute drafters about the appropriate standard of care is based on a disagreement about the facts and not about principle. As stated in Part I of this paper, no one seems to question that owners and managers of unincorporated entities should be able to pick their own standard of care and that society's default rule should be the rule that most would pick in most situations. ${ }^{48}$ The disagreement here is about the facts. ${ }^{49}$ Which standard of care, negligence or gross negligence, is the efficient and fair standard? Which standard would most parties in most cases agree upon? For the reasons articulated above, my firm view of the facts based on my own preferences and my experiences as a lawyer and in business is that, if fully informed and able to bargain, parties in most cases would settle upon a negligence standard of care.

Even if there is some uncertainty about my factual assumption that in most cases the parties would agree on a negligence standard of care, doubts about this should be resolved in favor of the higher standard. This is because the higher standard promotes more fully informed bargaining. ${ }^{50}$

48 See supra notes 24-33 and accompanying text.

49 See supra notes $37-39$ and accompanying text.

5o The argument I make here is similar to the argument that scholars have made against always using majoritarian default rules. Majoritarian rules are those that most parties would select in most cases. In some instances, however, a non-majoritarian default rule may promote efficient outcomes by improving the quality of information, as one party attempts to bargain its way out of the default rule and is thus induced to share more information with the other party in order to convince the other party to agree to opt out of the default rule. See, e.g., Ian Ayres, Making a Difference: The Contractual Contributions of Easterbrook and Fischel, 59 U. CHI. L. Rev. 1391, 1397-98 (1992) (using as an example a default rule that permits piercing the corporate veil for undisclosed undercapitalization). 
A statutory default standard of care becomes a part of the contract between the owner and the manager without the terms of the rule being physically included in the written partnership or LLC operating agreement. This incorporation without express reference increases the likelihood that investors in unincorporated business entities will misunderstand the nature of the fiduciary duty of care owed to them by their manager. The risk is that investors may mistakenly assume and pay for a higher standard of care than gross negligence. ${ }^{51}$

Managers of unincorporated business entities operate from the superior side of informational asymmetry. They normally control the entity documents and have ready access to the entity's lawyer, who can explain and counsel the managers regarding the terms of the entity agreement and is most likely willing to fashion documents that suit the preferences of the managers. Investors, on the other hand, typically enjoy no such advantages.

Bargaining between the parties is enhanced by setting a higher standard of care and thus requiring the managers who wish to opt into a lower standard of care to include the reduced standard of care in the actual partnership or LLC operating agreement. It increases, at least to some degree, the probability that investors are fully informed about the actual standard of care, since it will be in the document they sign and, hopefully, read and understand. ${ }^{52}$

In summary, efficiency and fairness are promoted by a negligence standard as opposed to a gross negligence standard of care. Negligence, at least in my view of the facts, amounts to the more efficient standard. It is the standard that parties would agree upon in most cases, if they were fully informed. A negligence standard also reduces the problem of asymmetry

51 In Ian Ayres, YA-HUH: There Are and Should Be Penalty Defaults, 33 FLA. ST. L. Rev. 589 (2006), Professor Ayres defends the use of non-majoritarian default rules (i.e., default rules that are not the rules that most parties would select) in instances where there is asymmetrical information about legal rights, which is what $\mathrm{I}$ argue in the case of fiduciary duties applicable to managers of unincorporated entities. "The 'legal information-forcing' rules are most plausible when there is asymmetric information about the content of the law itself. In the face of asymmetric legal information, a straightforward solution is to set the default against the more knowledgeable party." Id. at 597.

52 My argument here is not that the more rigorous standard of care will remedy all information asymmetry between managers and investors in unincorporated business entities. Managers would still have available, for example, the tactic of facilitating investor ignorance by burying a reconstituted standard of care deep in a long and complex partnership or LLC operating agreement. Nonetheless, if we force managers to communicate the standard of care it moves toward full disclosure between the parties. Also, as I suggest later, the uniform acts should be amended to require that any opt out of the duty of care must be disclosed prominently in writing on the outside front cover page of the partnership or LLC operating agreement. My view is that these two provisions together-enhancing the standard and requiring prominent disclosure of any opt out-would generate an improvement in fully informed bargaining by the parties. See infra notes $57-58,60-61$ and accompanying text. 
of information between managers and investors in unincorporated business entities by requiring that any reduction in that standard be agreed upon by the parties.

2. Opting Out of the Duty of Care.-ULLCA, RUPA and ULPA (2001) all have similar provisions permitting the parties to opt out of the statutory, gross negligence standard of care. All of the Acts require that the opt out provision be in the partnership or LLC operating agreement and that the reconstituted standard for the duty of care not unreasonably reduce the statutory gross negligence standard..$^{53}$

In discussing the principles in Part I of this paper, I offered the familiar argument that opt out provisions tend to promote fairness and efficiency. In instances where there are no material third-party effects, permitting parties to refashion a default rule to suit their own preferences generally facilitates the creation of economic value.

The prior discussion emphasized, however, that to achieve their maximum fairness and efficiency, opt out provisions must be inexpensive to access, and parties exercising the right to opt out must be fully informed..$^{54}$ If the expense of opting out exceeds the economic value created by opting out, parties will not exercise the right to opt out but will, instead, accept an inefficient default rule. If parties offered the right to opt out are less than fully informed, they may accept an inefficient default rule or agree to an inefficient reconstituted rule. ${ }^{55}$

Under the uniform acts, the statutory provisions applicable to opting out of the default standard of care are, as a procedural matter, simple and thus inexpensive to access. The only requirement is that any opt out arrangement be included in the partnership or operating agreement. Normally, one would imagine that the agreement would be in writing ${ }^{56}$ and includ-

53 See Appendix A infra.

54 See supra notes 33-39 and accompanying text for a discussion of opt out provisions and conditions for maximum efficiencies from such provisions.

55 Some recent interesting empirical work conducted by Professor Listokin supports this economic theory. His work demonstrates that default rules impact outcome. Professor Listokin examined the extent to which corporations adopt certain anti-takeover rules. As a part of this, he compared states that enacted Fair Price statutes as default rules with states that had no Fair Price statutes. He found: "Only $20 \%$ of companies incorporated in states without 'Fair Price' statutes choose to write fair price protection into their corporate charters ....Almost all companies (more than 96\%) in states where fair price protection is the default rule have fair price protection." Yair Listokin, What Do Corporate Default Rules and Menus Do? An Empirical Examination, Yale Law \& Economics Research Paper No. 335, at 6, available at http://papers.ssrn.com/abstract $=924578$. Assuming that an cfficient level of use of fair price statutes would be roughly the same from state to state, the data suggest an inefficient level of use of fair price provisions in one or both of the groups of states.

56 It is permissible for partnership and LLC operating agreements to be oral. See, e.g., RUPA § 101 (7) (2007) (defining a partnership agreement as an "agreement, whether written, oral or implied ...."). Normally, however, those agrecments are likely to be written. Even if 
ing an additional provision dealing with the reconstituted standard of care should not be too expensive.

The real problem in achieving efficiency through opting out of the standard of care, however, is the lack of full information. It seems likely that in many cases one side of the opt out bargain-specifically, investors-may be less than fully informed at the point when the opt out decision occurs. Managers have both the opportunity and the incentive to exploit this information asymmetry.

While information asymmetry between managers and investors about the standard of care is ameliorated to some extent by the procedural requirement that the opt out terms be included in the partnership or LLC operating agreement, there remains a significant and persistent opportunity for managers to exploit their information advantages through reconstituted bargains respecting the duty of care. As described above, ${ }^{57}$ managers control the construction of the essential entity documents, ${ }^{58}$ which puts them on the advantageous side of the informational asymmetry and enables them to generate entity documents that suit their preferences. On the investors side of the opt out bargain, on the other hand, it seems unlikely that a remade and relaxed standard of care on page twenty-two of a forty page, single-spaced partnership agreement or LLC operating agreement would be understood by most investors. ${ }^{59}$

Managers may have a pecuniary incentive to exploit this information asymmetry through opting into a very low standard of care. Simply stated, managers may have a preference to be paid at a high level commensurate with a strong duty of care standard while actually being subject to a lax standard of care. Their strategic informational advantages permit them to accomplish this and thus exploit what is an inefficient and unfair bargain with their investors.

One step that might reduce this asymmetry of information between managers and investors is based on an approach taken by the Securities and Exchange Commission with regard to disclosure of risk factors in a

oral, any party wishing to secure an opt out from the default loyalty rules would seem to have an interest in a written record of any opt out terms and proof that the investors had agreed to those terms.

57 See supra notes $5 \mathrm{I}-52$ and accompanying text.

$5^{8}$ In my own practice experience, in which I dealt with many unincorporated business entities, inevitably, the person who established the terms of the arrangement was the one who performed management functions for the business. It was, as an illustration, the general partner in limited partnerships and the managing partner in general partnerships who came to my office to have the partnership agreement crafted.

59 Loewenstein, supra note 27 , at 28 . "[T] ment may be very long and complex. Terms that relate to fiduciary duties may not be collected in one section; instead, terms ... may appear in various sections dealing with management, distributions, repurchase of units, etc." Id. Later he says: "the investor may not, in fact, be fully informed or sufficiently sophisticated ...." Id. at 29. 
registration statement. For years the Commission, consistent with its disclosure mandate, has required or encouraged issuers prominently to display or reference-critical information, such as risk factors, in bold type on the outside front cover page of the prospectus. ${ }^{60}$ In economic terms, the SEC is attempting to ensure that unique and significant risks are understood and priced by the trading parties, in that case the issuer and the investors in the public offering.

Applying this general approach to duty of care opt out provisions makes perfect sense. It is a way to increase the probability that investors involved in opting out of the default standard of care are more fully informed.

An effective opt out, therefore, should depend not only on the inclusion of the opt out terms in the partnership or LLC operating agreement but also on the disclosure of the opt out on the outside front cover page of the partnership or LLC operating agreement. At a minimum, that disclosure should prominently, concisely and in plain English describe and explain the statutory default standard of care and the reconstituted standard of care and, if necessary, cross-reference more detailed opt out provisions elsewhere in the agreement. ${ }^{61}$

60 Item 1 of Registration Form S-3, 2 CCH Federal Securities Law Reporter 9 7 I51, for example, incorporates by reference Item 50r of Regulation SK. I7 C.F.R. $\$ 229.501$ (2006), 7 $\mathrm{CCH}$ Federal Securities Law Reporter 971,051 . Item $501(\mathrm{~b})(5)$ requires the issuer to state on the "outside front cover page of the prospectus ... [a] cross-reference to the risk factors section .. [and to] [h] lighlight this cross-reference by prominent type or in another manner." Instructions regarding the content of the risk factors section are found in Item 503 (c) of Regulation SK. 17 C.F.R. § 229.503(c) (2006), 7 CCH Federal Securities Law Reporter 9 71,053 .

61 Language in the uniform acts permitting the opt out of the duty of care might include the following:

Any change in the statutory standard of care shall be prominently, concisely and in plain English explained and disclosed on the first page of the [partnership/operating] agreement. In the event the [partnership/ operating] agreement is not in writing, each [partner/member] prior to becoming a [partner/member] shall be supplied with a concise and clear written explanation and disclosure of any change in the statutory standard of care, and thereafter any subsequent change in the standard of care shall be preceded by a prominent, concise and plain English explanation and disclosure of the proposed change in the standard of care.

The proposal does not provide specific language necessary to meet the prominently, concisely and in plain English criteria. This should be left to the parties, along with the residual risk that the default standard will be applicable, if they fail to meet the three criteria designed to promote full information. While this will increase transaction costs somewhat--principally due to the residual risk if the promoting party gets it wrong-fiduciaries, who likely will be controlling the construction of the documents, will have a strong self interest in constructing a disclosure that meets the rigorous criteria and thus promotes full disclosure. 
A more dramatic and factually problematic prescription for inefficient opt outs is to impose a more restrictive limit on the right to opt out of the statutory duty of care. The present floor on the right to opt out of the statutory standard of care is that the remade standard cannot unreasonably reduce the statutory, gross negligence standard. My view is that raising this mandatory floor, if properly tailored, would enhance efficient and fair outcomes.

The theoretical underpinning for my argument in favor of a higher mandatory floor on the duty of care was described in Part II of this paper. Limiting the right to opt out makes economic sense in situations where parties, operating under unrestricted opt out rights, tend to opt out of more efficient rules into less efficient rules. If, on balance, the losses from parties opting into less efficient standards exceed the gains from parties' opting into more efficient standards, overall efficiency is enhanced by restricting the right to opt out. ${ }^{62}$ It is this analysis that justifies expanding the mandatory scope of the statutory duty of care by further limiting the right to opt out of the duty of care under the ULLCA, RUPA and ULPA (2001).

In estimating the efficient floor or limitation on the right to opt out of the duty of care, I start from the assumption, previously stated, that the efficient standard of care is a negligence standard, which obligates managers to act reasonably. ${ }^{63}$ My judgment is that in most cases fully informed parties in unincorporated business entities would agree that managers should act reasonably and that, accordingly, managers violate their fiduciary duties by acting unreasonably or negligently. ${ }^{64}$ My further factual reckoning is, however, that in some instances this negligence standard of care may not amount to a standard particular parties prefer. Some managers may be reluctant, without a significant increase in management fees, to accept that tough negligence standard, and some investors may be unwilling to pay the price that managers demand for the higher standard. In short, there seems to be significant efficiency gains in permitting parties by agreement to reduce the statutory negligence standard to a gross negligence standard. Under a gross negligence standard, managers would not breach their fiduciary duties by acts that are merely negligence but, instead, would breach their duty of care only if their actions were so unreasonable as to amount to an extreme deviation from reasonable care.

It is hard for me, however, to find net gains in efficiency by allowing parties to drop below a gross negligence standard and thus, for example, agree to predicate managerial liability on a "bad faith" standard or an "intentional acts of misconduct" standard. These very lax standards of care would permit managers with impunity to engage in conduct that is so stu-

62 See supra notes 24-35 and accompanying text. 63 See supra notes $43-48$ and accompanying text. 64 See supra notes $47-49$ and accompanying text. 
pid or unreasonable that it amounts to an extreme deviation from reasonable care, and this is the bargain that I find highly improbable. Only in the rarest of cases can I imagine that the parties knowingly would agree to such an extremely lax standard of care.

My factual reckoning, therefore, is that the loss of efficiency in denying parties the right to opt into a standard more lax than gross negligence is slight. ${ }^{65}$

On the other hand, denying parties the right to opt into an extremely lax "bad faith" or "intentional acts of misconduct standard" may enhance efficiency by curbing managers' exploitation of asymmetrical information. The economic incentive and opportunity of managers to construct an opt out into such extremely lax standards without the full knowledge of investors represents a significant threat to efficiency. Preventing such activity represents a significant gain in efficiency.

My view, therefore, is that net gains in efficiency are achieved by setting the opt out floor at a gross negligence standard. The economic costs in denying parties the right to opt into extremely relaxed standards of care seem immaterial, while the economic gains appear significant.

Opt out provisions are an integral part of efficient duty of care rules. The opt out provisions in the Acts fail to promote fair and efficient outcomes, however, principally because they facilitate managers' construction of opt outs that are based on less than full information. Managers have both the tactical advantage and the pecuniary incentive to exploit their informational advantages. Efficient and fair outcomes would be promoted by requiring opt outs to be disclosed on the outside front cover page of the partnership or LLC operating agreement and by limiting duty of care opt outs to gross negligence.

\section{B. Duty of Loyalty}

1. The Standard.-The statutory duty of loyalty is essentially the same under the ULLCA, RUPA and ULPA(2001). ${ }^{66}$ Fiduciaries operating under those statutes violate their duty of loyalty in four instances. ${ }^{67}$ These involve situations in which fiduciaries: (1) profit or derive benefit as a result of the

65 Approaching this matter in a non-economic manner, one may also have difficulty in finding any public policy that is furthered by permitting and encouraging managers to operate in such a highly careless way. Economists, however, especially those attracted to Kantian moral theory, would argue that any limitation on the right of rational humans to exercise their autonomy should be respected, even if their preferences are outside the mainstream. For a discussion of the application of Kantian moral theory to economics, see JEFFrIE G. MURPHY \& Jules L. Coleman, Philosophy of Law $70-82$ (rev. ed. 1990).

66 See APPENDIX A infra, for duty of loyalty provisions from RUPA, ULLCA and ULPA (2001).

67 As a matter of structure, the loyalty sections in all three of the uniform acts are broken into only three subsections. See, e.g., Section $404(b)$ of RUPA in APPENDIx A infra. 
conduct of the entity's business; ${ }^{68}$ (2) usurp an entity opportunity; (3) deal with the entity while having an interest adverse to the entity; or (4) compete with the entity.

All of the Acts make these four matters the exclusive duties of loyalty for the managers of the entities. Subsections (a) of the statutes describe the express statutory duties as the "only fiduciary duties" that the managers owe to the entities and the owners. ${ }^{69}$ For good measure, the specific duties of loyalty subsection in each of the statutes states that the duty of loyalty "is limited to" those four specific aspects of loyalty. ${ }^{70}$

The loyalty standards in ULLCA, RUPA and ULPA (2001) can lead to inappropriate outcomes, principally because of the exclusivity of the four specific loyalty rules. ${ }^{71}$ Compared to such an exclusivity approach, a broadly articulated duty of loyalty better promotes fair and efficient outcomes by providing stronger deterrence against managerial self dealing and promoting more informed bargaining. A broadly articulated standard of loyalty also allows courts to offer remedies in response to evolving forms of self-interested managerial misconduct.

The common law jurisprudence of Delaware corporate law captures in the intrinsic fairness standard what amounts to an efficient duty of loyalty rule, both in terms of the substance of the rule and the generality or breadth of its articulation. Substantively, the core of Delaware's approach to the loyalty obligation of corporate fiduciaries is the sensible and efficient principle that managers owe a higher fiduciary duty to shareholders when managers' actions are conflicted. This seems likely to approximate the agreement that fully informed investors and managers would construct for themselves, if they were able to bargain over the matter, and thus is similar to the duty courts have fashioned to apply to other fiduciaries and their beneficiaries. Trustees, for example, are similarly subjected to higher fiduciary standards when they engage in conflicted transactions on behalf of their trusts. ${ }^{72}$

68 Interestingly, this provision is copied from the Uniform Partnership Act of $1914 \S$ 2 I ( 1 ) [hereinafter UPA] (requiring a partner to "account to the partnership" for any "profits derived by him without the consent of the other partners" in connection with the "conduct" of the partnership) and is in all three of the uniform acts. See APPENDIX A infra.

69 See, e.g., RUPA Section 404(a) in APPENDIX A infra.

70 See, e.g., RUPA Section 404(b) in APpEndix A infra.

71 Perhaps as much as any other aspect of the fiduciary duty rules in the uniform acts, the exclusivity of the four loyalty rules supports a public choice or capture explanation for the failure to enact efficient standards. See supra notes $18-23$ and accompanying text. This strongly pro-management approach to the duty of loyalty with its increased probability of managers' exploitation of informational asymmetries is difficult to explain other than as reflecting the undue influence of managers' preferences for inefficient bargains respecting the duty of loyalty.

72 "As long as [a trustee] ... is not acting in his own interest the standard fixed for his behavior is only that of a reasonable degree of care, skill, and caution. But when the trustee 
Weinberger v. UOP, Inc. ${ }^{73}$ is the best known application of this basic loyalty rule to conflicted corporate fiduciaries. In Weinberger the court held that the burden was on conflicted directors to demonstrate that their actions in facilitating a freezeout of minority shareholders were entirely fair to those minority shareholders. ${ }^{74}$ This intrinsic fairness standard amounts to an enhanced substantive standard-entire fairness instead of the business judgment standard of gross negligence ${ }^{75}$ - and a procedural shift that assigns the burden of proof to the defendant.

Not only is an enhanced, intrinsic fairness standard itself efficient, but Delaware's broad formulation of the standard, as opposed to the four discrete and exclusive rules of the ULLCA, RUPA and ULPA (2001), promotes fairness and efficiency as well. It seems unlikely that the owners of the entities, had they thought about it, would have agreed to cabin fiduciary duties in four rather specific rules.

Business transactions and, unfortunately, managerial misconduct are in a perpetual state of evolution. As a result, investors in unincorporated business entitles are not well served by any attempt to cabin the duty of loyalty within four specific rules. ${ }^{76}$ Specific, exclusive rules invite managers to construct transactions that evade the spirit and underlying purpose of those rules and as a result visit unfair and unbargained for results on the beneficiaries of managers' fiduciary duties. ${ }^{77}$ It seems safe to assume, therefore,

acts in his own interest in connection with the performance of his duties as trustee, the standard of behavior becomes more rigorous." 2A Austin Wakeman Scott \& William Franklin Fratcher, The Law of Trusts § 170.25 (4th ed. 1987); see also Succession of Simpson, 311 So.2d 67, 72 (La. App. 1975).

73 Weinberger v. UOP, Inc., 457 A.2d 701 (Del. 1983).

$74 \mathrm{Id}$. at 703 (approving the substantive standard of unfairness of the merger terms to the minority; allocating the ultimate burden of proof to the majority shareholders)

75 While the core of the intrinsic fairness rule is sensible and efficient, the Delaware courts have made a mess of other matters relating to fiduciary duties. One such problem the courts have had is in articulating a consistent and intelligible duty of care under the business judgment rule. See, e.g., William T. Allen, Jack Jacobs \& Leo E. Strine, Jr., Realigning the Standard of Revieve of Director Due Care with Delaware Public Policy: A Critique of Van Gorkom and its Progeny as a Standard of Review Problem, 96 Nw. U. L. Rev. 449, 453 (2002) (equating gross negligence with a "rationality standard," and then admitting that "Delaware courts have chosen a definition of gross negligence [i.e., rationality] that is even more difficult for a plaintiff to establish than the gross negligence standard normally applied in American tort or criminal cases").

76 Bill Callison has suggested omitting all statutory fiduciary duties from statutes governing unincorporated associations. See Callison, supra note 16, at 485 ("state legislatures should excise fiduciary duty statements from the [limited liability company] statutes they enact").

77 An example of how the common law process operating with a basic, broadly articulated rule of enhanced fiduciary duties in conflicted situations can result in good outcomes is demonstrated by the development of the proportionality rule by the Delaware courts. The proportionality standard, also referred to as the enhanced business judgment test or the Unocal test, appeared in Unocal Corp. v. Mesa Petroleum Co., 493 A.2d 946, 954-55 (Del. 1985). Outside of Unocal, the most prominent application of the standard was in Revlon, Inc. v. MacAndrews 
that most fully informed investors would insist on a loyalty standard that offered protection against new and novel forms of conflicted managerial misconduct and the chance of a remedy in the event that such misconduct caused harm to them and their fellow investors.

A broadly articulated standard of loyalty also may promote more informed bargaining between managers and investors in unincorporated business entities. The very breadth of such a rule will put more pressure on managers attempting to opt out of the broad loyalty provision to include more well-crafted, explicit opt out provisions in the partnership or LLC operating agreement. Managers control the entity documents, and economic efficiency is enhanced by rules that provide an incentive for managers' documents to state clearly the rights of the parties.

Legislatures considering these uniform acts can improve fairness and efficiency by making the four categories of prohibited conflicted conduct non-exclusive, a matter that is easily accomplished by adding statutory language stating simply that the managers' duties of loyalty "include," but are not limited to, the four categories. ${ }^{78}$ Fairness and efficiency are improved because this approach more likely is the arrangement the parties would have agreed upon, will enhance bargaining information by providing an incentive for the party controlling the documents-the entity's managersto include more specific opt out language in the partnership or operating agreement, and will enable courts to offer remedies against new forms of abusive conduct on the part of managers.

2. Opting Out of the Duty of Loyalty.-All three of the uniform acts provide similar provisions for opting out of the statutory duty of loyalty provisions. Each act requires the terms of the opt out and the reconstituted duties of

\& Forbes Holdings, Inc., 506 A.2d 173, 180 (Del. 1985). The proportionality standard is based on the accurate observation that corporate fiduciaries sometimes act in situations that are to some extent conflicted but less so than the deep conflict that justifies the use of the intrinsic fairness standard. The court in Unocal characterized these situations as involving a "specter" of a conflict, ("omnipresent specter that a board may be acting primarily in its own interests"), and, accordingly, developed a fiduciary standard that falls somewhere between business judgment and intrinsic fairness. Unocal Corp., 493 A.2d at 954 . Under the proportionality standard, the quasi-conflicted corporate fiduciaries are held to a substantive standard of negligence or reasonableness, Id. at 955 , which is higher than the business judgment standard of gross negligence but seemingly less strict than the intrinsic fairness substantive standard. Procedurally, the proportionality test assigns the burden of proof to the quasi-conflicted fiduciary. Id. Generally, courts have limited the use of the proportionality rule to the evaluation of board actions taken in response to unsolicited takeover bids. But see Omnicare, Inc. v. NCS Healthcare, Inc., 818 A.2d 914, 935 (Del. 2003) (applying the proportionality test in a friendly acquisition).

78 Some states in the adoption of uniform acts have taken just this step. Kentucky is an example of this. In adopting RUPA, Kentucky's legislature changed the loyalty provisions of RUPA to state that the "partner's duty of loyalty ... includes but is not limited to" the exclusive categories of RUPA. Kr. Rev. StAT. ANN. \$§ 362.1-404(2) (West 2007). 
loyalty to be contained in the partnership or LLC operating agreement. The right to opt out of the duty of loyalty also is limited in that the parties cannot entirely eliminate the duty of loyalty, and any reconstituted duty of loyalty cannot be manifestly unreasonable. ${ }^{79}$

The same principles used in Part II.A.2 of this paper to evaluate duty of care opt out provisions are appropriately applicable to evaluate duty of loyalty opt out provisions. Restating those principles briefly: (1) opt out provisions generally tend to promote efficient and fair outcomes; (2) maximum efficiency and fairness gains from opt out provisions require inexpensive access to the opt out provisions and fully informed parties; and (3) efficiency and fairness goals may dictate a limit on the opt out right, if parties tend to opt out of efficient arrangements into inefficient arrangements.

Loyalty opt out provisions create a significant opportunity for net efficiency gains ${ }^{80}$ by, for example, permitting parties to opt out of the prohibition against competing with the entity. Consider an illustration based on experience from my own prior practice. In my last tour of duty as a transactional lawyer, I used unincorporated business entities as vehicles for constructing deals in the horse industry. A typical transaction involved a limited or general partnership that was put together and managed by an experienced horseman who in his personal capacity was involved in all or most aspects of the horse business. This raised the possibility that the manager of the partnership would compete with the partnership in breeding, buying, selling and racing horses. It was this very factor-the experience of the manager - that made the deal attractive to investors, however, and it would have been nearly impossible to find a capable manager who would not be in competition with the partnership. In short, opting out of a prohibition of competition was an efficient term. It created value for the parties.

The efficiency generating characteristics of loyalty opt outs are enhanced by the statutes' procedural simplicity. The only procedural requirements in the statutes are that any loyalty opt out term must be specific and contained in the partnership or LLC operating agreement. ${ }^{81}$ As a result, loyalty opt outs can be accessed without undue costs, which promotes efficiency. ${ }^{82}$

79 See APPENDix A infra.

80 Broadly available loyalty opt out rights, at least in my view, create more of an opportunity for efficiency gains than do broadly available duty of care opt out rights. As described in Part II.A.2., permitting parties to reduce the standard of care below a gross negligence standard generates net inefficiencies, since it is highly unlikely that fully informed parties would agree to such an extremely lax standard of care. See supra notes $60-62$ and accompanying text. On the other hand, broad flexibility to opt out of the loyalty obligation can generate value for the parties, as is demonstrated in my example based on my practice in the horse industry, which immediately follows in the text.

81 See APPENDix A infra.

82 See supra note 30 and notes $50-55$ and accompanying textual discussion. 
The requirements that the opt out terms be specific and contained in the partnership or LLC operating agreement also enhance efficiency by promoting more fully informed decision making by the parties, most importantly on the part of investors. Requiring the opt out to be included in the partnership or LLC agreement increases the probability that the investors will know of and, hopefully, understand the terms of the opt out ${ }^{83}$ The probability that investors are fully informed is further increased by a specificity requirement, which states that the opt out "may not ... eliminate the duty of loyalty ... but ... may identify specific types or categories of activities that do not violate the duty of loyalty ...." ${ }^{84}$ This specificity requirement means, for example, that generalized language, such as, "partners [managers] shall owe no duty of loyalty to the partnership [LLC] or the partners [members]," would be unenforceable. Managers attempting to opt out of a portion of the duty of loyalty, therefore, have a strong incentive to convey to investors full information about the scope of the opt out.

While these provisions move the parties toward more complete information respecting loyalty opt outs, further improvement on the matter of information asymmetry could be made by using the same technique proposed in Part II.A.2 of this paper in regard to duty of care opt outs. Specifically, the Acts governing partnerships, limited partnerships and LLCs should also predicate any opt out of the duty of loyalty on the disclosure of the opt out on the outside front cover page of the partnership or LLC operating agreement. At a minimum, that disclosure should prominently, concisely and in plain English describe the terms of the loyalty opt out and, if necessary, cross-reference more detailed opt out provisions elsewhere in the agreement. Otherwise, managers who control the entity documents once again have the incentive and opportunity to bury loyalty opt out terms in the middle of a long and complex partnership or LLC operating agreement, which may allow managers to exploit their informational advantage by means of an inefficient bargain with investors. ${ }^{85}$

Finally, the statutes' "manifestly unreasonable" limitation on the loyalty opt out right seems appropriate in this case. In the duty of care situation, a more strictly limited opt out right is justified because of the likelihood that very few fully informed parties would ever agree to a standard of care that absolved managers of liability for an extreme deviation from ordinary care. As a result, no significant efficiency gains were apparent by permitting the parties to opt into such extremely lax standards of care. In

83 While partnership and LLC operating agreements may be oral, see, e.g., RUPA § 10I(7) (defining a partnership agreement as an "agreement, whether written, oral or implied"), even in that case it seems likely that managers attempting to opt out of the loyalty rules would produce some written record to support their opt out claim. See supra note 53 and accompanying text of opting out of the duty of care.

84 See, e.g., RUPA § 103(b), at APPEndix A infra.

85 See supra notes $53-5^{8}$ and accompanying text. 
the case of duty of loyalty opt out standards, however, broad and generous standards are essential to enable parties to construct the many efficiency enhancing arrangements that they may desire, and a standard set at manifestly unreasonable may be about right in that regard. The example I used above-a partnership where the partners waive the loyalty prohibition against competition-is only one example of the efficiency generating effect of broad loyalty opt out provisions. ${ }^{86}$ Parties must be permitted substantial flexibility in order to construct the myriad of efficiency generating loyalty opt outs that will suit their particular preferences and thus generate economic value.

To maximize the efficiencies created by such a broad opt out right, however, it is essential that the opt out be coupled with provisions that provide strong incentives for full information sharing among the parties at the point of the opt out. The provisions described above-requiring that the opt out be in specific terms and be included in the partnership or LLC operating agreement, and adding a requirement that the opt out be prominently disclosed on the outside front cover page of the partnership or LLC operating agreement-become even more important because of the broad and generous loyalty opt out rights.

In summary, the broad loyalty opt out provisions found in ULLCA, RUPA and ULPA (2001) generally tend to promote efficient and fair outcomes. The provisions allow a low cost opt out and are structured in a way to enhance the extent to which the parties exercising the opt out are fully informed. As was the case with the duty of care opt out, however, full information on the part of parties could be further enhanced by conditioning any loyalty opt out on a prominent, concise and intelligible statement of the opt out on the outside front cover page of the partnership or LLC operating agreement.

\section{Conclusion}

Somewhere along the way, the uniform unincorporated business statutesULLCA, RUPA and ULPA (2001) - got off track in the area of fiduciary duties. A public choice analysis suggests that the misdirection was the result of the fact that managers of unincorporated business entities as a group were best able to overcome collective action problems and thus bend the uniform acts to their preferences.

The unfortunate result is that the uniform acts facilitate managers' creation of inefficient and self-serving bargains between themselves and

86 Referring back to my experience in practice of putting together deals in the horse industry, see supra note 80 and accompanying text, managers in those deals not only were typically in competition with the partnership but also were selling products and services to the partnership, in the form, for example, of boarding and foaling services. Once again, these arrangements created value for the parties. 
investors regarding managers' fiduciary duties. The default rules are inefficient and unduly pro-management, and the statutory opt out provisions enable the creation of even more inefficient and pro-management terms. Operating under the uniform acts, managers of unincorporated business entities can exploit their informational and strategic advantages and generate untoward pecuniary gains for themselves at the expense of investors.

This is a matter of some importance for the economy and society. Millions of small businesses operate as partnerships and LLCs, ${ }^{87}$ and small businesses are a vital part of our economy. They provide many essential services and products in our society and employment for millions of workers. Data from the Small Business Administration show, for example, that nearly twenty percent of all employment in the United States is provided by small firms having less than twenty employees. ${ }^{88}$ Research also suggests that small businesses are vehicles for much of the entrepreneurial initiative so important for a market economy ${ }^{89}$ Society needs efficient and fair rules of governance and capital formation for this very important portion of our economy.

In future revisions of the uniform acts, NCCUSL Committees will have the opportunity to change the Acts' inefficient and pro-management fiduciary duty provisions, as will state legislatures when in the future they adopt or amend any of the uniform acts. These important societal rule makers-NCCUSL and state legislatures-should be guided by morally attractive, consent-based principles, principles that will lead to enhanced fairness and efficiency in regard to the fiduciary duties of managers of unincorporated business entities.

87 See, e.g., Melvin Aron Eisenberg, Corporations and Other Business Organizations CASES AND MATERials 499 (9th ed. 2005) (describing the numbers of general partnerships, limited partnerships and LLCs and the extreme growth in the numbers of LLCs in recent years).

88 See U.S. Small Business Administration, Office of Advocacy, The Small Business Economy: A Report of the President 2005, at $216-1$, Table A.5 (2005), available at http:// www.sba.gov/advo/research/sb_econ2005.pdf. According to the data, in 2002, the last year included in the REPORT, $18.3 \%$ of all employees in the United States were employed in business firms that had less than twenty employees. The total number of persons employed by these small firms was 20,583,371. Id.

89 See id. at 183-204. "This paper has gone beyond the observation that breakthrough advance in technology is predominately a small firm specialty. There is a good deal of evidence that this has been the case for over a century and that it continues to be so today." Id. at 204. 


\section{APPENDIX A}

Section 404 of the RUPA states:

(a) The only fiduciary duties a partner owes to the partnership and the other partners are the duty of loyalty and the duty of care set forth in subsections (b) and (c).

(b) A partner's duty of loyalty to the partnership and the other partners is limited to the following:

(1) to account to the partnership and hold as trustee for it any property, profit, or benefit derived by the partner in the conduct and winding up of the partnership business or derived from a use by the partner of partnership property, including the appropriation of a partnership opportunity;

(2) to refrain from dealing with the partnership in the conduct or winding up of the partnership business as or on behalf of a party having an interest adverse to the partnership; and

(3) to refrain from competing with the partnership in the conduct of the partnership business before the dissolution of the partnership.

(c) A partner's duty of care to the partnership and the other partners in the conduct and winding up of the partnership business is limited to refraining from engaging in grossly negligent or reckless conduct, intentional misconduct, or a knowing violation of law.

(d) A partner shall discharge the duties to the partnership and other partners under this [Act] or under the partnership agreement and exercise any rights consistently with the obligation of good faith and fair dealing.

(e) A partner does not violate a duty or obligation under this [Act] or under the partnership agreement merely because the partner's conduct furthers the partner's own interest.

(f) A partner may lend money to and transact other business with the partnership, and as to each loan or transaction the rights and obligations of the partner are the same as those of a person who is not a partner, subject to other applicable law.

(g) This section applies to a person winding up the partnership business as the personal or legal representative of the last surviving partner as if the person were a partner. 
Section 103 of the RUPA states:

(a) Except as otherwise provided in subsection (b), relations among the partners and between the partners and the partnership are governed by the partnership agreement. To the extent the partnership agreement does not otherwise provide, this [Act] governs relations among the partners and between the partners and the partnership.

(b) The partnership agreement may not:

(3) eliminate the duty of loyalty under Section 404(b) ..., but:

(i) the partnership agreement may identify specific types or categories of activities that do not violate the duty of loyalty, if not manifestly unreasonable; or

(ii) all of the partners or a number or percentage specified in the partnership agreement may authorize or ratify, after full disclosure of all material facts, a specific act or transaction that otherwise would violate the duty of loyalty;

(4) unreasonably reduce the duty of care under Section 404(c) or 603(b)(3)...

Section 408 of the ULPA (2001) states:

(a) The only fiduciary duties that a general partner owes to the limited partnership and the other partners are the duty of loyalty and care under subsections (b) and (c).

(b) A general partner's duty of loyalty to the limited partnership and the other partners is limited to the following:

(1) to account to the partnership and hold as trustee for it any property, profit, or benefit derived by the partner in the conduct and winding up of the partnership business or derived from a use by the partner of partnership property, including the appropriation of a partnership opportunity;

(2) to refrain from dealing with the partnership in the conduct or winding up of the partnership business as or on behalf of a party having an interest adverse to the partnership; and

(3) to refrain from competing with the partnership in the conduct of the partnership business before the dissolution of the partnership.

(c) A general partner's duty of care to the partnership and the other partners in the conduct and winding up of the partnership business is limited to refraining from engaging in grossly negligent or reckless conduct, intentional misconduct, or a knowing violation of law. 
(d) A general partner shall discharge the duties to the partnership and other partners under this [Act] or under the partnership agreement and exercise any rights consistently with the obligation of good faith and fair dealing.

(e) A general partner does not violate a duty or obligation under this [Act] or under the partnership agreement merely because the partner's conduct furthers the partner's own interest.

Section 110 of the ULPA (2001) states:

(a) Except as otherwise provided in subsection (b), the partnership agreement governs relations among the partners and between the partners and the partnership. To the extent the partnership agreement does not otherwise provide, this [Act] governs relations among the partners and between the partners and the partnership.

(b) A partnership agreement may not:

(5) eliminate the duty of loyalty under Section 408 , but the partnership agreement may:

(A) identify specific types or categories of activities that do not violate the duty of loyalty, if not manifestly unreasonable; and

(B) specify the number or percentage specified of partners which may authorize or ratify, after full disclosure to all the partners of all material facts, a specific act or transaction that otherwise would violate the duty of loyalty;

(6) unreasonably reduce the dury of care under Section 408(c).

Section 409 of the ULLCA states:

(a) The only fiduciary duties a member owes to a member-managed company and its other members are the duty of loyalty and the duty of care imposed by subsections (b) and (c).

(b) A member's duty of loyalty to a member-managed company and its other members is limited to the following:

(1) to account to the company and to hold as trustee for it any property, profit, or benefit derived by the member in the conduct or winding up of the company's business or derived from a use by the member of the company's property, including the appropriation of a company's opportunity.

(2) to refrain from dealing with the company in the conduct or winding up of the company's business as or on behalf of a party having an interest adverse to the company; and 
(3) to refrain from competing with the company in the conduct of the company's business before the dissolution of the company.

(c) A member's duty of care to a member-managed company and its other members in the conduct of and winding up of the company's business is limited to refraining from engaging in grossly negligent or reckless conduct, intentional misconduct, or a knowing violation of law.

(d) A member shall discharge the duties to a member-managed company and its other members under this [Act] or under the operating agreement and exercise any rights consistently with the obligation of good faith and fair dealing.

(e) A member of a member-managed company does not violate a duty or obligation under this [Act] or under the operating agreement merely because the member's conduct furthers the member's own interest.

(f) A member of a member-managed company may lend money to and transact other business with the company. As to each loan or transaction, the rights and obligations of the member are the same as those of a person who is not a member, subject to other applicable law.

(g) This section applies to a person winding up the limited liability company's business as the personal or legal representative of the surviving member as if the person were a member.

(h) In a manager-managed company:

(1) a member who is not also a manager owes no duties to the company or to the other members solely by reason of being a member;

(2) a member is held to the same standards of conduct prescribed for members in subsections (b) through (f);

(3) a member who pursuant to the operating agreement exercises some or all of the rights of a manager in the management and conduct of the company's business is held to the standards of conduct in subsections (b) and through (f) to the extent that the member exercises the managerial authority vested in a manager by this [Act]; and

(4) a member is relieved of liability imposed by law for violation of the standards prescribed by subsections (b) through ( $f$ ) to the extent of the managerial authority delegated to the members by the operating agreement. 
Section 103 of the ULLCA provides:

(a) Except as otherwise provided in subsection (b), all members of a limited liability company may enter into an operating agreement, which need not be in writing, to regulate the affairs of the company and the conduct of its business, and to govern relations among the members, managers, and company. To the extent the operating agreement does not otherwise provide, this [Act] governs relations among the members, managers, and company.

(b) The operating agreement may not:

(2) eliminate the duty of loyalty under Section 409 (b) ..., but the agreement may:

(i) identify specific types or categories of activities that do not violate the duty of loyalty, if not manifestly unreasonable; and

(ii) specify the number or percentage specified of partners that may authorize or ratify, after full disclosure of all material facts, a specific act or transaction that otherwise would violate the duty of loyalty;

(3) unreasonably reduce the duty of care under Section 409 (c) or 603(b)(3). 